\title{
Milk and Cheese from Cows Fed Calcium Salts of Palm and Fish Oil Alone or in Combination with Soybean Products ${ }^{1}$
}

\author{
S. L. Allred, ${ }^{\star}$ T. R. Dhiman, ${ }^{\star 2}$ C. P. Brennand, $†$ R. C. Khanal, ${ }^{\star}$ D. J. McMahon, $\dagger$ and N. D. Luchini‡ \\ *Department of Animal, Dairy and Veterinary Sciences, Utah State University, Logan 84322-4815 \\ †Department of Nutrition and Food Sciences, Utah State University, Logan 84322-8700 \\ łBioproducts, Inc., Fairlawn, OH 44333
}

\section{ABSTRACT}

Twenty cows were used in a randomized block design experiment for $6 \mathrm{wk}$ to determine the influence of feeding partial ruminally inert Ca salts of palm and fish oil (Ca-PFO), alone or in combination with extruded full-fat soybeans or soybean oil, on milk fatty acid (FA) methyl esters composition and consumer acceptability of milk and Cheddar cheese. Cows were fed either a diet containing $44 \%$ forage and $56 \%$ concentrate (control) or a diet supplemented with $2.7 \% \mathrm{Ca}-\mathrm{PFO}$ (FO), $5 \%$ extruded full-fat soybeans $+2.7 \%$ Ca-PFO (FOESM), or $0.75 \%$ soybean oil $+2.7 \%$ Ca-PFO (FOSO). Total dietary FA content in the control, FO, FOESM, and FOSO diets were 4.61, 6.28, 6.77, and $6.62 \mathrm{~g} / 100 \mathrm{~g}$, respectively. There was no difference in nutrient intake, milk yield, or milk composition among treatments. Conjugated linoleic acid (CLA) $\mathrm{C}_{18: 2} \mathrm{cis}-9$, trans-11 isomer, $\mathrm{C}_{18: 1}$ trans-11 (VA), and total n-3 FA in milk from cows on the control, FO, FOESM, and FOSO treatments were $0.56,1.20,1.36$, and $1.74 ; 3.29$, $4.66,6.34$, and $7.81 ; 0.62,0.69,0.69$, and $0.67 \mathrm{~g} / 100 \mathrm{~g}$ of FA, respectively. Concentrations of CLA, VA, and total n-3 FA in cheese were similar to milk. A trained sensory panel detected no difference in flavors of milk and cheese, except for acid flavor below a slightly perceptible level in cheese from all treatments. Results suggest that feeding $\mathrm{Ca}-\mathrm{PFO}$ alone or in combination with extruded full-fat soybeans or soybean oil enhanced the CLA, VA, total unsaturated and n-3 FA in milk and cheese without negatively affecting cow performance and consumer acceptability characteristics of milk and cheese.

Key words: milk, fatty acid, fish oil, conjugated linoleic acid

Received March 20, 2005.

Accepted August 21, 2005.

${ }^{1}$ Approved as Journal Paper Number 7668 of the Utah Agricultural Experiment Station, Utah State University, Logan.

${ }^{2}$ Corresponding author: trdhiman@cc.usu.edu

\section{INTRODUCTION}

Fat not only provides energy in the diet, but also has an important role for promoting good health in humans (Parodi, 1994). As lipid research has increased over the last century, the health benefits of long-chain fatty acids (FA) have been recognized. Conjugated linoleic acid (CLA) has been shown to have potential health benefits, including anticarcinogenic properties in experimental animals (Pariza, 1999; Hughes and Dhiman, 2002). The primary isomers of CLA that have been associated with health benefits are the $\mathrm{C}_{18: 2}$ cis9, trans-11 (CLA-1) and $\mathrm{C}_{18: 2}$ trans-10, cis-12 (CLA2) FA (Pariza, 1999; Park et al., 1999). The principal dietary sources of CLA are dairy and meat products from ruminant animals. The average CLA-1 content of whole milk varies from 0.30 to $0.55 \mathrm{~g} / 100 \mathrm{~g}$ of FA (Dhiman et al., 1999a). The CLA content of milk and meat products from ruminants can be increased through manipulations of the diet, such as grazing on pasture or feeding feed sources rich in linoleic and linolenic acids (Dhiman et al., 1999a,b). Vaccenic acid $\left(\mathrm{C}_{18: 1}\right.$ trans- $\left.11 ; \mathrm{VA}\right)$ also has potential health benefits because VA can be converted to CLA-1 in the human (Turpeinen et al., 2002) and animal (Corl et al., 2001) body through the enzyme $\Delta^{9}$-desaturase.

Based on a 30-yr epidemiological study, Kromhout (1989) reported that low levels of eicosapentaenoic acid (EPA; $\left.\mathrm{C}_{20: 5} \mathrm{n}-3\right)$ and docosahexaenoic acid (DHA; $\mathrm{C}_{22: 6}$ $\mathrm{n}-3)$ result in a significant decrease in the incidence of coronary heart disease. The n-3 FA have also been shown in animal and human studies to be necessary for growth, development, immunity, and insulin activity (Vessby, 2000; Calder, 2001; Uauy et al., 2001).

Increasing the concentrations of beneficial dietary FA (CLA, VA, and n-3 FA) and maintaining a favorable ratio between $n-3$ and $n-6$ FA in milk will enhance the nutritive and therapeutic value of dairy products. Previous research has shown that feeding fish oil at $2 \%$ of dietary DM to dairy cows increased the concentrations of CLA and VA in milk FA and decreased daily feed intake and fat content of milk (Chouinard et al., 1999; Donovan et al., 2000; Baer et al., 2001; Ramas- 
wamy et al., 2001). A feed source of fish oil and soybean oil that increases the proportions of healthful FA on milk but does not negatively affect feed intake and milk fat content and is easy to handle will be more acceptable at the farm level.

Our hypothesis is that feeding feedstuffs rich in linoleic acid and partially ruminally inert source of fish oil will supply substrate in the rumen for CLA synthesis and source of n-3 FA postruminally for direct absorption in the small intestine without negatively affecting feed intake and milk fat content. Our objective was to enhance CLA and n-3 FA while maintaining feed intake, milk fat content, and comparable flavor characteristics of milk and cheese that are acceptable to consumers.

\section{MATERIALS AND METHODS}

\section{Experimental Design and Treatments}

Twenty multiparous Holstein dairy cows averaging $165 \pm 61 \mathrm{DIM}$ and producing $46.6 \pm 5.3 \mathrm{~kg}$ of milk/d were blocked into 5 groups according to average milk yield from $1 \mathrm{wk}$ prior to the start of the experiment. Average BW of experimental cows at the start of the experiment was $756.1 \pm 47.4 \mathrm{~kg}$. Cows within each group were randomly assigned to 1 of 4 treatments. Experimental duration was $6 \mathrm{wk}$, including a 3-wk diet adaptation. Measurements were made during the last $3 \mathrm{wk}$. Cows in the 4 treatments were fed either a control, basal diet containing $44 \%$ forage and $56 \%$ concentrate or a basal diet containing $2.7 \%$ partially ruminally inert Ca salts of palm and fish oil (Ca-PFO) (FO), 5\% extruded full-fat soybeans $+2.7 \% \mathrm{Ca}-\mathrm{PFO}$ (FOESM), or $0.75 \%$ soybean oil $+2.7 \% \mathrm{Ca}-\mathrm{PFO}$ (FOSO). Bioproducts Inc. (Fairlawn, $\mathrm{OH}$ ) supplied CaPFO containing $16 \mathrm{~g}$ of fish oil/100 g of salt. Full-fat extruded soybeans were prepared by extruding whole soybeans at 146 to $149^{\circ} \mathrm{C}$ using an Insta-Pro Extruder Model 2500 (Insta-Pro Int., Division of Triple "F", Inc., Des Moines, IA). Ingredient composition of treatment diets is given in Table 1. Extruded full-fat soybeans and oil supplements were added by replacing corn and soybean meal in the basal diet. Diets were formulated to meet the nutrient requirements of cows producing $50 \mathrm{~kg}$ of $3.5 \% \mathrm{FCM} / \mathrm{d}$ according to NRC (2001) recommendations and fed as a TMR. The soybean oil was stored in a cold room at $4^{\circ} \mathrm{C}$ and was added fresh to the diet each morning to avoid oxidation. The Ca-PFO was stored in 22.7-kg airtight bags, in a covered, cool, and dry feed barn. Cows were housed in a tie-stall barn and fed individually once daily ad libitum $(0700$ h); amounts fed and refused were recorded daily. Orts were restricted to 5 to $10 \%$ of daily intake on an asfed basis. Animal care and procedures were approved and conducted under established standards of the Utah State University Institutional Animal Care and Use Committee.

Daily TMR samples were frozen at $-20^{\circ} \mathrm{C}$. Orts from individual cows were composited for each treatment, and a representative sample was frozen at $-20^{\circ} \mathrm{C}$ for subsequent analysis. Weekly composite samples of TMR and orts were analyzed for DM content. Samples of forages and other feed ingredients were collected once weekly and analyzed for DM. The DM content of the feed ingredients was determined by oven-drying at $60^{\circ} \mathrm{C}$ for $48 \mathrm{~h}$. Dietary formulations were adjusted weekly, if necessary, to account for small changes in ingredient DM content.

Dried feed samples were ground through a Wiley mill (1-mm screen; Arthur H. Thomas, Philadelphia, PA) and analyzed for chemical composition. The CP content of feed samples was determined using the macro Kjeldahl nitrogen test using AOAC method 954.01 (AOAC, 2000) with a Kjeltec digester 20 and Kjeltec System 1026 distilling unit (Tecator AB, Hoganas, Sweden). The NDF and ADF contents were determined with the ANKOM $^{200}$ Fiber Analyzer (Ankom Technology Corporation, Fairport, NY), using the basic procedure of Van Soest et al. (1991). Sodium sulfite was not used in the procedure for NDF determination, but pre-treatment with heat-stable amylase (Type XIA from Bacillus subtilis, Sigma-Aldrich Corporation, St. Louis, MO) was included. Weekly samples of dietary ingredients were analyzed for total FA content and FA profile (Sukhija and Palmquist, 1988). During analysis, the samples were further dried at $105^{\circ} \mathrm{C}$ for $8 \mathrm{~h}$ to determine the absolute DM, and chemical analyses were expressed on the basis of this final absolute DM.

The chemical composition of the TMR was calculated from the chemical composition of individual ingredients of the diet. Daily DMI for individual cows was calculated by subtracting the weekly mean of orts from the weekly mean of feed offered. The $\mathrm{NE}_{\mathrm{L}}$ content of the diet was calculated by using the $\mathrm{NE}_{\mathrm{L}}$ table values (NRC, 2001) for the individual dietary ingredients (Table 1). Weekly mean $\mathrm{NE}_{\mathrm{L}}$ intakes were calculated by multiplying the $\mathrm{NE}_{\mathrm{L}}$ values of the diet by the mean DMI of the individual cows for that week. The CP, NDF, and FA intakes were calculated by subtracting CP, NDF, and FA amounts in orts from feed offered. The amount of CP, NDF, and FA in orts was calculated by multiplying weekly mean orts for individual cows by treatment average $\mathrm{CP}, \mathrm{NDF}$, and FA content in orts during that week.

\section{Diet Composition}

Chemical composition of the treatment diets is presented in Table 1. Mean DM content of the treatment 
Table 2. Fatty acid composition of the treatment diets and Ca salts of palm and fish oil (Ca-PFO)

\begin{tabular}{|c|c|c|c|c|c|}
\hline \multirow[b]{2}{*}{ Fatty acid $^{1}$} & \multicolumn{4}{|c|}{ Treatment $^{2}$} & \multirow[b]{2}{*}{$\mathrm{Ca}-\mathrm{PFO}$} \\
\hline & CTL & FO & FOESM & FOSO & \\
\hline & \multicolumn{5}{|c|}{$\longrightarrow(\mathrm{g} / 100 \mathrm{~g}$ of fatty acids reported $)$} \\
\hline $\mathrm{C}_{10: 0}$ & 0.03 & 0.03 & 0.03 & 0.03 & 0.04 \\
\hline $\mathrm{C}_{12: 0}$ & 0.00 & 0.10 & 0.09 & 0.09 & 0.36 \\
\hline $\mathrm{C}_{14: 0}$ & 3.84 & 3.57 & 3.33 & 3.38 & 2.81 \\
\hline $\mathrm{C}_{14: 1}$ & 1.38 & 1.03 & 0.96 & 0.98 & 0.03 \\
\hline $\mathrm{C}_{15: 0}$ & 0.11 & 0.14 & 0.13 & 0.13 & 0.20 \\
\hline $\mathrm{C}_{16: 0}$ & 17.92 & 25.31 & 24.36 & 24.70 & 45.03 \\
\hline $\mathrm{C}_{16: 1}$ & 0.25 & 0.73 & 0.69 & 0.70 & 2.03 \\
\hline $\mathrm{C}_{17: 1}$ & 7.11 & 5.26 & 4.98 & 4.98 & 0.21 \\
\hline $\mathrm{C}_{18: 0}$ & 3.15 & 3.53 & 3.66 & 3.54 & 4.53 \\
\hline $\mathrm{C}_{18: 1} c-9$ & 19.47 & 23.56 & 23.53 & 23.38 & 34.59 \\
\hline $\mathrm{C}_{18: 2} c-9,12(\mathrm{n}-6)$ & 39.37 & 31.06 & 32.36 & 32.29 & 8.96 \\
\hline $\mathrm{C}_{18: 3} c-6,9,12(\mathrm{n}-6)$ & 0.00 & 0.01 & 0.01 & 0.04 & 0.03 \\
\hline $\mathrm{C}_{18: 3} c-9,12,15(\mathrm{n}-3)$ & 5.50 & 4.25 & 4.53 & 4.40 & 0.62 \\
\hline $\mathrm{C}_{20: 3} c-11,14,17(\mathrm{n}-3)$ & 0.00 & 0.01 & 0.01 & 0.01 & 0.02 \\
\hline $\mathrm{C}_{20: 5} c-5,8,11,14,17(\mathrm{n}-3)$ & 0.77 & 0.59 & 0.55 & 0.56 & 0.08 \\
\hline $\mathrm{C}_{22: 4} c-7,10,13,16(\mathrm{n}-6)$ & 1.01 & 0.75 & 0.70 & 0.71 & 0.09 \\
\hline $\mathrm{C}_{22: 5} c-7,10,13,16,19(\mathrm{n}-3)$ & 0.10 & 0.09 & 0.08 & 0.08 & 0.07 \\
\hline
\end{tabular}

proportions of $\mathrm{C}_{16: 0}$ and $\mathrm{C}_{18: 1}$ cis-9 in diets compared with the control treatment.

\section{Milk Collection and Processing}

Milk yields were recorded daily on an individual cow basis. Weekly milk samples were collected on an individual cow basis from 4 consecutive a.m. and p.m. milkings (at 0530 and $1730 \mathrm{~h}$ ) during 4, 5, and 6 wk of the experiment. A Broad Spectrum Microtabs II (D \& F Control Systems Inc., San Ramon, CA) preservative was added, and the milk was stored at $4^{\circ} \mathrm{C}$. During wk 5 and 6 , cows were milked out from 2 consecutive milkings from each treatment group, in vacuumsealed milking cans. The milk was transferred into stainless-steel cans, labeled for treatment identification, and transported within $45 \mathrm{~min}$ from the dairy to the Gary H. Richardson Dairy Products Laboratory on the Utah State University campus. Upon arrival at the Dairy Laboratory, milk was transferred to fresh stainless-steel milking cans to avoid any transmission of bacteria from the dairy to the laboratory. The milk was cooled to $4^{\circ} \mathrm{C}$ within $2 \mathrm{~h}$ after collection by placing the stainless-steel milking cans in vats containing ice water. Eighteen kilograms of milk per cow per milking were combined for each treatment, pasteurized at $73^{\circ} \mathrm{C}$ for $16 \mathrm{~s}$ using an APV Model SR15-S (APV Equipment Inc., Tonawanda, NY), and stored in stainless-steel cans at $4^{\circ} \mathrm{C}$ for cheese manufacturing. A portion of the pasteurized milk (approximately $10 \mathrm{~kg}$ ) from each treatment was homogenized using a Gaulin model
CGC 2-stage homogenizer (Gaulin, Everette, MA) at 787.6 and $196.9 / \mathrm{cm}^{2}$. Homogenized milk was stored in a clear plastic bag with tube dispenser. Sensory evaluation of milk was conducted within $72 \mathrm{~h}$ of procurement and within $36 \mathrm{~h}$ of processing the milk without standardizing for fat content.

\section{Cheddar Cheese Manufacturing}

Cheddar cheese was prepared using the small-scale manufacturing procedure used at the Dairy Products Laboratory, Utah State University, in stainless-steel, steam-jacketed rectangular cheese vats. Each cheese vat was filled with approximately $230 \mathrm{~kg}$ of pasteurized milk adjusted to $31^{\circ} \mathrm{C}$ for ideal culture growth. Lyophilized cultures of Lactococcus lactis ssp. lactis and L. lactis ssp. cremoris blend plus selected adjunct cultures as required for specific flavor profiles were added to the vat and were allowed to ripen for $30 \mathrm{~min}$. Calcium chloride was added to aid coagulation after the inoculant, during the ripening process, and diluted with cold water to a ratio of 10:1. Color was added using single strength annatto (DSM Food Specialties, Heerlen, NL) at a level of $20 \mathrm{~mL} / 100 \mathrm{~kg}$ of milk and diluted with cold water to 20:1. Double-strength Maxiren coagulant (Maxiren double strength, DSM Food Specialties, Menomonee Falls, WI) was added and diluted to 20:1 with cold chlorine-free water and stirred in the vat. The contents of the vat sat undisturbed for $30 \mathrm{~min}$ and then were cut into 3-dimensional cube curd. The curd was heated slowly over $10 \mathrm{~min}$ to $33^{\circ} \mathrm{C}$ 
and then to $39^{\circ} \mathrm{C}$ over the next $20 \mathrm{~min}$. The curd was cooked for $45 \mathrm{~min}$, and the whey was drained. The curd mat was then cut and rotated to keep it warm. The cheese mat was cut into pieces using a cheese mill and salted over 3 applications at a rate of $6.27 \mathrm{~kg}$ of salt $/ 1,000 \mathrm{~kg}$ of milk. Salted cheese curd $(11.4 \mathrm{~kg})$ was placed in each of 2 sanitized stainless-steel, $10-\mathrm{kg}$ cheese hoops with disposable plastic cheesecloth. Hoops were labeled with the treatment identification and pressed overnight. Two vats of cheese (one from each treatment) were made on the same day (during wk 5 and 6) with a total of eight $10-\mathrm{kg}$ blocks of cheese being produced. Cheddar cheese was vacuum-packaged in air-tight plastic bags and stored at $4^{\circ} \mathrm{C}$ until evaluated for sensory parameters at $21,30,90$, and $180 \mathrm{~d}$ of aging.

\section{Compositional Analysis of Milk and Cheese}

Individual milk samples were analyzed for fat, true protein, lactose, and urea by the Rocky Mountain DHIA Laboratory (Logan, UT) with mid-infrared wavebands (2 to $15 \mu \mathrm{m}$ ) procedures using a Bentley 2000 (Bentley Instruments, Chaska, MN). The infrared instrument was calibrated weekly using raw milk standards based on chemistry analysis (Eastern Laboratory Services Limited, Fairlawn, $\mathrm{OH}$ ). The fat measurement channel used was a combination of Fat A and Fat B. Final milk composition for each week was expressed on weighted milk yield of a.m. and p.m. samples. Average fat and protein yields were calculated by multiplying milk yield from the respective week by fat and protein content of the milk on an individual cow basis. Energy-corrected milk was calculated on an individual cow basis using milk yield, fat, and protein content (Tyrrell and Reid, 1965). Gross feed efficiency was calculated by dividing daily ECM by DMI on an individual cow basis.

Weekly weighted composite milk samples from individual cows were analyzed for FA composition, including CLA, VA, and n-3 FA. Milk fat was extracted by boiling the milk in a detergent solution (Hurley et al., 1987) using the procedures and gas chromatography conditions described by Dhiman et al. (1999b, 2002). Samples containing methyl esters in hexane ( 1 to 3 $\mu \mathrm{L})$ were injected through the split-less injection port onto a Supelcowax 10, fused silica capillary column $(100 \mathrm{~m} \times 0.32 \mathrm{~mm}$., $0.25-\mu \mathrm{m}$ film thickness; Supelco Inc., Bellefonte, PA). Fatty acids were identified by comparing the retention times with methylated FA standards including CLA (Nu-Chek Prep, Elysian, MN; Matreya, Pleasant Gap, PA; Supelco Inc.). Heptadecanoic acid was used as a qualitative internal standard. The CLA reported is CLA- 1 and CLA-2. Percent- age of each FA was calculated by dividing the area under the FA peak (minus the area under the peak for heptadecanoic acid) by the sum of the areas under the total reported FA peaks. Fatty acids were reported as grams $/ 100 \mathrm{~g}$ of FA methyl esters. Different $\mathrm{C}_{18: 1}$ trans and cis FA were not identified because of the limitations of column used in the gas chromatography. In the present study, an acidic catalyst was used for FA methyl ester preparation. Studies have shown that recovery of CLA is lower when using an acid catalyst as compared with a base catalyst (Kramer et al., 1997; Murrieta et al., 2003). Though the values reported in this study are lower than would be determined using a basic catalyst for methylation, relative comparisons among treatments should still be valid. Treatment differences in CLA levels in muscle were not affected by use of acidic methylation catalysts (Murrieta et al., 2003).

To compare the influence of methylation procedures on FA profiles, cheese samples were methylated using both acidic (Chin et al., 1992) and alkaline (Chouinard et al., 1999) procedures. Extracted fat was derivatized to methyl esters using an alkaline methylation procedure by mixing $40 \mathrm{mg}$ of fat with a sodium methoxide methylation reagent $\left(\mathrm{NaOCH}_{3} / \mathrm{MeOH}\right)$ as described by Chouinard et al. (1999) with minor modifications. After FA methyl esters were formed, anhydrous calcium chloride pellets were added and allowed to stand for $1 \mathrm{~h}$ to remove water in the sample. Samples were then centrifuged at $2,600 \times g$ at $5^{\circ} \mathrm{C}$ for $5 \mathrm{~min}$. Separation of FA was achieved by gas chromatography (model 6800 Series II, Hewlett Packard Co., Avondale, PA) fitted with a flame-ionization detector. The FA methyl esters in hexane were injected through a 40:1 split injection port with $\mathrm{He}$ as a carrier gas. Oven temperature was set for $70^{\circ} \mathrm{C}$ and held for 4 min then was ramped to $120^{\circ} \mathrm{C}$ at $8^{\circ} \mathrm{C} / \mathrm{min}$. The temperature was then ramped to $200^{\circ} \mathrm{C}$ at $7^{\circ} \mathrm{C} / \mathrm{min}$ and held for $10 \mathrm{~min}$ and then ramped to $225^{\circ} \mathrm{C}$ at $4^{\circ} \mathrm{C} / \mathrm{min}$ and held for 18 min. Finally, the temperature was ramped to $235^{\circ} \mathrm{C}$ at $8^{\circ} \mathrm{C} / \mathrm{min}$. Injector and detector were set at $250^{\circ} \mathrm{C}$. Heptadecadenoic acid was used as qualitative internal standard. Each peak was identified using FA and FA methyl esters (Nu-Chek Prep; Matreya; and Supelco 37 Component FAME mix, Supelco Inc.). Individual cheese samples were tested for FA profiles every $4 \mathrm{wk}$ for $24 \mathrm{wk}$ to determine the influence of aging of cheese on CLA content. The CLA yield was calculated by multiplying CLA content with total fat yield corrected for glycerol content (Chouinard et al., 2001) on an individual cow basis.

The VA is converted to CLA in the mammary gland (Corl et al., 2001) via the $\Delta^{9}$-desaturase enzyme. The 
$\Delta^{9}$-desaturase index was calculated for selected milk FA using product-to-substrate ratios of FA. The FA ratios used to determine the $\Delta^{9}$-desaturase index were $\mathrm{C}_{14: 1}: \mathrm{C}_{14: 0}, \mathrm{C}_{16: 1}: \mathrm{C}_{16: 0}, \mathrm{C}_{18: 1}$ cis-9: $\mathrm{C}_{18: 0}$, and $\mathrm{C}_{18: 1}$ trans11:CLA-1.

Fatty acids can promote or prevent atherosclerosis and coronary thrombosis based on their effects on serum cholesterol and low density lipoprotein-cholesterol concentrations (Ulbright and Southgate, 1991). The equations proposed by Ulbright and Southgate (1991) for the atherogenic (AI) and thrombogenic indices (TI) indicated that the $\mathrm{C}_{12: 0}, \mathrm{C}_{14: 0}$, and $\mathrm{C}_{16: 0} \mathrm{FA}$ are atherogenic and that $\mathrm{C}_{14: 0}, \mathrm{C}_{16: 0}$, and $\mathrm{C}_{18: 0}$ are thrombogenic. The $n-3, n-6$, and monounsaturated FA are antiatherogenic and antithrombogenic. The ratio between the 2 is used to calculate the AI and TI.

The AI and TI were calculated in the present study using the equations described by Ulbright and Southgate (1991). In equations, the $\mathrm{C}_{14: 0} \mathrm{FA}$ is considered to be 4 times more atherogenic than the other FA; thus, the coefficient " 4 " has been assigned to it. The $\mathrm{C}_{18: 1} \mathrm{n}-6$ and monounsaturated $\mathrm{FA}$ have been assigned coefficients of 0.5 because they are less antiatherogenic than the n-3 FA, which have been assigned a coefficient of 3 .

\section{Sensory Evaluation of Milk and Cheese}

A trained panel of judges evaluated pasteurized and homogenized fluid milk samples of wk 5 and 6 from each treatment on 3 and $10 \mathrm{~d}$ of storage, for acid, barny, cooked, feed, fermented, foreign, stale, oily, oxidized, rancid, overall quality, and specific flavors on a scorecard patterned after the American Dairy Science Association scoring guide (Hammond et al., 1986). Seven judges were selected from a group of people who had been regularly exposed to training and judging a variety of dairy products, including fluid milk. Judges were not specifically trained for the current study, but were familiar with the scorecard for fluid milk flavor. The sensory testing was conducted by using a continuous 9point scale for flavor characteristics, where $9=$ highly pronounced flavor, $7=$ moderate, $5=$ slight, $3=$ barely perceptible, and $1=$ none. Overall quality of milk was rated on a continuous scale of 1 to 10 , where $10=$ excellent in overall quality, $5=$ average, and $1=$ undesirable and unfit for sale. Whole milk fortified with vitamin $D$ in a clear plastic container was purchased from the store with at least a 14-d shelf-life and was used as a positive control. Reference samples for specific attributes were provided for all flavor characteristics during sampling.

Refrigerated $\left(22.0 \pm 1.0^{\circ} \mathrm{C}\right)$ fluid milk $(20 \mathrm{~mL})$ was served in plastic cups to a trained panel. Random code numbers were assigned for identification of each sample, but the order of sample presentation was not randomized among panelists. The evaluation of milk from wk 5 and 6 was conducted in individual booths under fluorescent white light. Water and spittoons were provided to panelists to cleanse the palate between samples. This was repeated after a 20-min break. Sample position was changed each time samples were offered to judges.

Nine experienced panelists evaluated Cheddar cheese samples from each treatment on $21,30,90$ and $180 \mathrm{~d}$ of storage for acid, bitter, color, feed, fermented, flat, oily, oxidized, rancid, sulfide, unclean, and overall quality using a modified official American Dairy Science Association scorecard (Hammond et al., 1986) for cheese flavors. The panelists were selected from among people who had been regularly exposed to training on dairy products, including Cheddar cheese. The panelists were previously trained for quantitative descriptive sensory analysis, including training on the Cheddar cheese lexicon and the American Dairy Science Association scorecard. The scale used for specific flavors, uniformity of color, and overall quality of cheese by the trained panel was the same as was used for milk.

For evaluation, cheese blocks were cut into cubes (1 $\mathrm{cm}^{3}$ ) and served to a panel of 9 judges. Cheese was served in plastic cups at room temperature $\left(22^{\circ} \mathrm{C}\right)$ with random code numbers assigned to each sample. All samples of cheese were tested the same day with breaks allowed for judges between trays of samples. All judges tested all samples. Flavor compounds were provided as reference for specific flavor attributes to the panelists while performing the test. Testing conditions were the same as described previously for milk. Judges were not provided information regarding the treatment of each sample in any of the previous evaluations.

\section{Estimation of Ruminal Protection of Fat in Ca Salts of Fish Oil}

The Ca-PFO were analyzed for ruminal protection of FA using a simple in vitro procedure. Rumen digesta was collected from ruminally cannulated cows fed a TMR containing $46 \%$ forage and $54 \%$ grain mixture in a thermos flask flushed with $\mathrm{CO}_{2}$. Digesta was strained through cheesecloth and mixed with McDougall's buffer in a ratio of 50:50. Duplicate samples of CaPFO were incubated $(1.20 \mathrm{~g} / 100 \mathrm{~mL}$ of incubation solution) in flasks in a $39.5^{\circ} \mathrm{C}$ water bath for 0 and $24 \mathrm{~h}$. Flasks were manually shaken every 2 to $3 \mathrm{~h}$. At the end of each time, flask contents were freeze-dried and analyzed for FA profile (Sukhija and Palmquist, 1988) as described earlier. To determine the level of fat pro- 
tection, sum of polyunsaturated $\mathrm{FA}\left(\mathrm{C}_{18: 2}\right.$ cis $-9,12 ; \mathrm{C}_{18: 3}$ cis- $9,12,15 ; \mathrm{C}_{18: 3}$ cis- $6,9,12, \mathrm{C}_{20: 3}$ cis- $8,11,14, \mathrm{C}_{20: 3}$ cis$11,14,17 ; \quad \mathrm{C}_{20: 5}$ cis-5,8,11,14,17; $\mathrm{C}_{22: 4}$ cis-7,10,13,16; $\mathrm{C}_{22: 5}$ cis-7,10,13,16,19) as a proportion of total FA at $0 \mathrm{~h}$ were compared with the 24 -h time point. At $0 \mathrm{~h}$, the total polyunsaturated FA level was $13.19 \%$ of the total FA. At the 24-h time point, the total polyunsaturated FA level decreased to $11.65 \%$. This suggests that polyunsaturated FA in the Ca-PFO were approximately $88.3 \%$ inert in the rumen degradation when incubated in the rumen fluid for $24 \mathrm{~h}$. In a review by Demeyer and Doreau (1999), it is stated that when diets are high in unsaturated FA and rumen $\mathrm{pH}$ is low, these factors will increase Ca salt dissociation in the rumen. Therefore, these data need careful interpretation because ruminal protection level for cows fed high-grain diets may actually be $<88.3 \%$. Calcium salts of unsaturated FA are more dissociated than $\mathrm{Ca}$ salts of saturated FA at any given ruminal $\mathrm{pH}$; this disassociation can also weaken the physical barrier surrounding the FA in a real-time ruminal situation (Lundy et al., 2004) and result in lower ruminal protection than observed in vitro.

\section{Statistical Analyses}

All statistical analyses were performed using the Mixed statistical procedure of SAS (1999-2000). Analyses on diet composition data were performed with treatment and week as the fixed effects. The significance level was declared at $P<0.05$ unless otherwise noted. Trends for significance were declared at $P=$ 0.05 to 0.10 . Analysis of intake data, milk yield, milk composition, FA composition, $\Delta^{9}$-desaturase enzyme index, AI, and TI were done using Proc Mixed in a repeated measures design. Treatment, block, week, and treatment $\times$ week were included in the model as fixed effects with week as the repeated measure on cows. Covariance structure was autoregressive (1). In the case of cheese FA profile, treatment, age, and treatment $\times$ age were included in a factorial model; week was the replicate. For the sensory panel on milk and cheese, treatment, judge, age, treatment $\times$ judge, treatment $\times$ age, judge $\times$ age, and treatment $\times$ judge $x$ age were included in the model; batch was used as the replicate. For the methylation procedure, the model was built in a stepwise manner deleting the factors with $\alpha>0.3$. Final model included treatment, method, and treatment $\times$ method.

\section{RESULTS AND DISCUSSION}

\section{Intake, Milk Yield, and Milk Composition}

The treatment by week interaction was nonsignificant for nutrient intake, milk yield, and milk composi- tion parameters. Therefore, average values of 4,5 , and $6 \mathrm{wk}$ for nutrient intake, production, and milk composition data are presented in Table 3. The DMI was not different among treatments despite the high level of fat in the FO, FOESM, and FOSO compared with the control diet. The addition of oil to the diet can depress DMI because of the increased energy content or its ability to coat fiber in the rumen, decreasing the activity of fibrolytic bacteria (Jenkins, 1993). No significant treatment differences in DMI resulted in similar intakes of $\mathrm{NE}_{\mathrm{L}}, \mathrm{CP}$, and NDF among treatments. Fat intake was higher for FO, FOESM, and FOSO than for the control because of the higher FA content in the diets of those treatments (Table 1).

Milk yield, ECM, ECM/DMI, and milk composition (except milk urea content) were similar among treatments (Table 3). Other researchers (Chouinard et al., 1999; Baer et al., 2001; Whitlock et al., 2002) have reported a significant decrease in milk fat with the addition of fish oil to the diet at $2 \%$ of the dietary DM. In the present study, there was a slight tendency for lower milk fat content in FOSO treatment, probably because of unsaturated FA from soybean oil (Dhiman et al., 1999b). Dairy farmers are paid premium price for higher milk fat. Therefore, even a small decrease in milk fat could be of economic value to dairy producers. Ramaswamy et al. (2001) reported that fish oil in combination with soybeans did not depress milk fat. Donovan et al. (2000) reported no decrease in milk protein yield if fish oil was supplemented at $<3 \%$ of the diet. In contrast, Whitlock et al. (2002) reported that in lactating cow diets, the addition of fish oil at $2 \%$ of the diet decreased the milk protein yield. Milk urea nitrogen was higher in FOESM, probably because of the numerically higher CP content of the diet for this treatment. No significant negative effects were observed in the present study on nutrient intake, milk production, and milk composition, which is probably due to the fact that partially ruminally inert fat supplement was used in the present study instead of free fish oil.

\section{FA Composition of Milk and Cheese}

The treatment by week interaction was nonsignificant for FA in milk and cheese; therefore average values of 4,5 , and $6 \mathrm{wk}$ of the experiment for milk FA composition are presented in Table 4. Data for FA composition of cheese are not presented because the trends among treatments for most FA were very similar to milk FA profile. The $\mathrm{C}_{4: 0} \mathrm{FA}$ was not reported because of low recovery during the gas chromatography analysis. The proportion of short-chain FA $\left(\mathrm{C}_{6: 0}\right.$ to $\mathrm{C}_{12: 0}$ ) decreased in milk and cheese for the FO, 
Table 3. Nutrient intake and milk production of cows fed Ca salts of palm and fish oil (Ca-PFO) alone or in combination with soybean products

\begin{tabular}{lcccccc}
\hline & \multicolumn{7}{c}{ Treatment $^{1}$} & & \\
\cline { 2 - 4 } Item & CTL & FO & FOESM & FOSO & SEM $^{2}$ & $P^{3}$ \\
\hline Intake, kg/d & & & & & & \\
DM & 28.8 & 26.9 & 26.5 & 26.1 & 1.02 & 0.30 \\
NE (Mcal/d) & 50.9 & 51.3 & 50.4 & 50.8 & 1.65 & 0.98 \\
CP & 4.83 & 4.53 & 4.52 & 4.35 & 0.17 & 0.30 \\
NDF & 9.68 & 9.15 & 9.01 & 8.73 & 0.35 & 0.32 \\
Fat & $0.93^{\mathrm{b}}$ & $1.28^{\mathrm{a}}$ & $1.42^{\mathrm{a}}$ & $1.29^{\mathrm{a}}$ & 0.70 & $<0.01$ \\
Production, kg/d & & & & & & \\
Milk yield & 40.8 & 41.0 & 39.6 & 39.1 & 2.68 & 0.95 \\
ECM & 39.7 & 38.9 & 37.0 & 35.0 & 2.12 & 0.42 \\
ECM/DMI & 1.38 & 1.44 & 1.38 & 1.34 & 0.69 & 0.81 \\
Fat yield & 1.38 & 1.33 & 1.27 & 1.11 & 0.11 & 0.12 \\
Protein yield & 1.18 & 1.14 & 1.05 & 1.06 & 0.09 & 0.42 \\
Milk composition, \% & & & & & & \\
Fat & 3.47 & 3.32 & 3.33 & 2.89 & 0.22 & 0.12 \\
Protein & 2.92 & 2.81 & 2.66 & 2.72 & 0.12 & 0.17 \\
Lactose & 4.76 & 4.60 & 4.55 & 4.51 & 0.11 & 0.19 \\
Milk urea N (mg/dL) & $11.4^{\mathrm{b}}$ & $12.2^{\mathrm{b}}$ & $14.0^{\mathrm{a}}$ & $13.0^{\mathrm{b}}$ & 0.50 & 0.02 \\
\hline
\end{tabular}

${ }^{\mathrm{a}, \mathrm{b}}$ Means in the same row with different superscripts differ significantly for treatment effect with $P$ value as mentioned in column for significance.

${ }^{1}$ Cows were fed a control, basal diet containing $44 \%$ forage and $56 \%$ concentrate mix (CTL) or a basal diet supplemented with (DM basis) $2.7 \%$ Ca-PFO (FO), $2.7 \%$ Ca-PFO + 5\% full-fat extruded soybeans (FOESM), or $2.7 \% \mathrm{Ca}-\mathrm{PFO}+0.75 \%$ soybean oil (FOSO).

${ }^{2} \mathrm{SEM}=$ Standard error of least square means.

${ }^{3}$ Significance for treatment effect.

${ }^{4} \mathrm{ECM}=0.327 \times$ milk $(\mathrm{kg})+12.95 \times$ fat $(\mathrm{kg})+7.20 \times$ protein $(\mathrm{kg}) ;$ Equation derived from Table 4 of Tyrrell and Reid (1965).

FOESM, and FOSO compared with the control. This supports the findings of Baer et al. (2001) who reported a decrease in short-chain FA as fish oil or soybean oil (Dhiman et al., 1999b) was added to the diet of lactating dairy cows. A decrease in several medium-chain FA $\left(\mathrm{C}_{14: 0}, \mathrm{C}_{15: 0}\right.$, and $\left.\mathrm{C}_{17: 1}\right)$ was also observed in milk and cheese in FO, FOESM, and FOSO compared with the control. The FO, FOESM, and FOSO also showed an increase in long-chain FA (VA, $\mathrm{C}_{18: 1}$ cis-9, $\mathrm{C}_{22: 4}$, $\mathrm{C}_{22: 5}$, and DHA) compared with the control for both milk and cheese, which is consistent with Baer et al. (2001), who reported the increase in long-chain FA with the addition of fish oil to the diet. The proportion of the $\mathrm{C}_{18: 0} \mathrm{FA}$ in milk tended to decrease with the addition of Ca-PFO alone or in combination with soybean products. The proportion of the $\mathrm{FA} \mathrm{C}_{20: 2}, \mathrm{C}_{20: 3}$ cis$11,14,17$, and EPA in milk showed a tendency toward increasing with the addition of Ca-PFO alone or in combination with soybean products compared with the control.

The proportions VA in milk FA increased by 1.37 , 3.05 , and $4.52 \mathrm{~g} / 100 \mathrm{~g}$ when $\mathrm{Ca}-\mathrm{PFO}$ was fed alone or in combination with extruded full-fat soybeans or soybean oil, respectively, compared with the control. Similar increases in the proportions of VA were observed in cheese from FO, FOESM, and FOSO treatments compared with cheese from the control. The increase in VA was more when Ca-PFO was fed in combination with soybean oil in free form. Whitlock et al. (2002) and Donovan et al. (2000) reported an increase in the VA of 4- and 5-fold with the addition of fish oil to the diet of lactating cows. The addition of a small amount of fish oil in a cow's diet increases the VA in milk FA because fish oil inhibits the enzyme responsible for the conversion of $\mathrm{VA}$ to $\mathrm{C}_{18: 0}$ in the ruminal biohydrogenation pathway, resulting in accumulation of VA in the rumen, which provides more VA to the mammary gland that can be converted to CLA by the $\Delta^{9}$-desaturase enzyme (Kay et al., 2004).

The CLA-1 in milk FA increased 2-, 2.4-, and 3-fold in the FO, FOESM, and FOSO treatments, respectively, compared with the control (Table 4). The proportion of CLA-1 in cheese was $0.58,1.07,1.34$, and $1.63(P<0.001) \mathrm{g} / 100 \mathrm{~g}$ of FA methyl esters in the control, FO, FOESM, and FOSO, respectively. Some of the differences seen in the FA composition of the milk and cheese can be attributed to the decreased variability of the cheese, as milk from all cows was pooled for each treatment and samples were taken from each batch of cheese for analysis in contrast with milk analysis, which was conducted on milk samples from individual cows $(n=18$ per treatment vs. 2; $\mathrm{SEM}=0.03$ vs. 0.13). Previous research has shown that feeding unsaturated oils increases CLA in milk 
Table 4. Fatty acid composition of milk from cows fed Ca salts of palm and fish oil (Ca-PFO) alone or in combination with soybean products

\begin{tabular}{|c|c|c|c|c|c|c|}
\hline \multirow[b]{2}{*}{ Fatty acid ${ }^{1}$} & \multicolumn{4}{|c|}{ Treatment $^{2}$} & \multirow[b]{2}{*}{$\mathrm{SEM}^{3}$} & \multirow[b]{2}{*}{$P^{4}$} \\
\hline & CTL & FO & FOESM & FOSO & & \\
\hline & \multicolumn{4}{|c|}{$\longrightarrow(\mathrm{g} / 100 \mathrm{~g}$ of fatty acids reported $)$} & & \\
\hline $\mathrm{C}_{6: 0}$ & $0.87^{\mathrm{a}}$ & $0.70^{\mathrm{b}}$ & $0.63^{\mathrm{b}}$ & $0.66^{\mathrm{b}}$ & 0.06 & $*$ \\
\hline $\mathrm{C}_{8: 0}$ & $0.87^{\mathrm{a}}$ & $0.58^{\mathrm{b}}$ & $0.48^{\mathrm{b}}$ & $0.53^{\mathrm{b}}$ & 0.05 & $* * *$ \\
\hline $\mathrm{C}_{10: 0}$ & $2.72^{\mathrm{a}}$ & $1.57^{\mathrm{b}}$ & $1.26^{\mathrm{b}}$ & $1.41^{\mathrm{b}}$ & 0.10 & $* * *$ \\
\hline $\mathrm{C}_{12: 0}$ & $3.62^{\mathrm{a}}$ & $2.08^{\mathrm{b}}$ & $1.70^{\mathrm{b}}$ & $1.93^{\mathrm{b}}$ & 0.14 & $* * *$ \\
\hline $\mathrm{C}_{14: 0}$ & $11.7^{\mathrm{a}}$ & $9.04^{\mathrm{b}}$ & $8.17^{\mathrm{b}}$ & $8.74^{\mathrm{b}}$ & 0.35 & $* * *$ \\
\hline $\mathrm{C}_{14: 1}$ & $0.51^{\mathrm{a}}$ & $0.58^{\mathrm{a}}$ & $0.35^{\mathrm{b}}$ & $0.47^{\mathrm{ab}}$ & 0.06 & 0.14 \\
\hline $\mathrm{C}_{15: 0}$ & $1.62^{\mathrm{a}}$ & $1.14^{\mathrm{b}}$ & $1.07^{\mathrm{b}}$ & $1.06^{\mathrm{b}}$ & 0.04 & $* * *$ \\
\hline $\mathrm{C}_{16: 0}$ & 32.2 & 34.1 & 32.2 & 33.1 & 0.62 & 0.17 \\
\hline $\mathrm{C}_{16: 1}$ & 1.82 & 1.82 & 1.74 & 1.78 & 0.14 & 0.97 \\
\hline $\mathrm{C}_{17: 1}$ & $0.23^{\mathrm{a}}$ & $0.20^{\mathrm{b}}$ & $0.19^{\mathrm{b}}$ & $0.18^{\mathrm{b}}$ & 0.01 & $* *$ \\
\hline $\mathrm{C}_{18: 0}$ & 13.1 & 11.5 & 12.2 & 10.9 & 0.51 & 0.06 \\
\hline $\mathrm{C}_{18: 1} t-11(\mathrm{VA})$ & $3.29^{\mathrm{c}}$ & $4.66^{\mathrm{b}}$ & $6.34^{\mathrm{ab}}$ & $7.81^{\mathrm{a}}$ & 0.50 & $* *$ \\
\hline $\mathrm{C}_{18: 1} c-9$ & $21.0^{\mathrm{b}}$ & $25.0^{\mathrm{a}}$ & $25.4^{\mathrm{a}}$ & $23.6^{\mathrm{a}}$ & 0.71 & $* *$ \\
\hline $\mathrm{C}_{18: 2}$ & 4.71 & 5.11 & 5.27 & 5.06 & 0.14 & 0.10 \\
\hline $\mathrm{C}_{18: 3} c-6,9,12$ & 0.06 & 0.06 & 0.06 & 0.06 & 0.005 & 0.76 \\
\hline $\mathrm{C}_{18: 3} c-9,12,15$ & 0.53 & 0.52 & 0.55 & 0.53 & 0.02 & 0.80 \\
\hline CLA $c-9, t 11$ & $0.56^{\mathrm{c}}$ & $1.20^{\mathrm{b}}$ & $1.36^{\mathrm{ab}}$ & $1.74^{\mathrm{a}}$ & 0.13 & $* * *$ \\
\hline CLA $t-10, c 12$ & $0.04^{\mathrm{b}}$ & $0.07^{\mathrm{a}}$ & $0.08^{\mathrm{a}}$ & $0.08^{\mathrm{a}}$ & 0.003 & $* * *$ \\
\hline Total CLA ${ }^{5}$ & $0.61^{\mathrm{c}}$ & $1.27^{\mathrm{b}}$ & $1.44^{\mathrm{ab}}$ & $1.82^{\mathrm{a}}$ & 0.13 & $* * *$ \\
\hline CLA yield, g/d & $7.5^{\mathrm{c}}$ & $14.7^{\mathrm{b}}$ & $16.0^{\mathrm{ab}}$ & $17.5^{\mathrm{a}}$ & 0.10 & $* * *$ \\
\hline $\mathrm{C}_{20: 2}$ & 0.05 & 0.06 & 0.06 & 0.06 & 0.004 & 0.07 \\
\hline $\mathrm{C}_{20: 3} c-8,11,14$ & $0.17^{\mathrm{a}}$ & $0.12^{\mathrm{b}}$ & $0.11^{\mathrm{b}}$ & $0.10^{\mathrm{b}}$ & 0.01 & $* * *$ \\
\hline $\mathrm{C}_{20: 3} c-11,14,17$ & 0.009 & 0.015 & 0.013 & 0.014 & 0.001 & 0.06 \\
\hline $\mathrm{C}_{20: 4}$ & $0.18^{\mathrm{a}}$ & $0.10^{\mathrm{b}}$ & $0.10^{\mathrm{b}}$ & $0.08^{\mathrm{b}}$ & 0.008 & $* * *$ \\
\hline $\mathrm{C}_{20: 5}(\mathrm{EPA})$ & 0.03 & 0.05 & 0.04 & 0.04 & 0.004 & 0.06 \\
\hline $\mathrm{C}_{22: 4}$ & $0.03^{\mathrm{a}}$ & $0.02^{\mathrm{b}}$ & $0.02^{\mathrm{b}}$ & $0.01^{b}$ & 0.002 & $* * *$ \\
\hline $\mathrm{C}_{22: 5}$ & $0.04^{\mathrm{b}}$ & $0.06^{\mathrm{a}}$ & $0.05^{\mathrm{a}}$ & $0.05^{\mathrm{a}}$ & 0.003 & $* *$ \\
\hline $\mathrm{C}_{22: 6}$ (DHA) & $0.01^{b}$ & $0.05^{\mathrm{a}}$ & $0.04^{\mathrm{a}}$ & $0.04^{\mathrm{a}}$ & 0.004 & $* * *$ \\
\hline Total n-3 fatty acids ${ }^{6}$ & $0.62^{\mathrm{b}}$ & $0.69^{\mathrm{a}}$ & $0.69^{\mathrm{a}}$ & $0.67^{\mathrm{ab}}$ & 0.02 & $*$ \\
\hline Total n-6 fatty acids ${ }^{7}$ & 5.15 & 5.41 & 5.56 & 5.31 & 0.14 & 0.30 \\
\hline n-3:n-6 & 0.118 & 0.129 & 0.121 & 0.125 & 0.003 & 0.10 \\
\hline Saturated fatty acids & $66.7^{\mathrm{a}}$ & $60.2^{\mathrm{b}}$ & $57.7^{\mathrm{b}}$ & $58.3^{\mathrm{b}}$ & 0.87 & *** \\
\hline Unsaturated fatty acids & $33.3^{\mathrm{b}}$ & $39.8^{\mathrm{a}}$ & $42.3^{\mathrm{a}}$ & $41.7^{\mathrm{a}}$ & 0.87 & $* * *$ \\
\hline
\end{tabular}

${ }^{\mathrm{a}, \mathrm{b}, \mathrm{c}}$ Means in the same row with different superscripts differ significantly for treatment effect with $P$ value as mentioned in column for significance.

${ }^{1}$ Expressed as number of carbons: number of double bonds; $c=c i s$ and $t=$ trans.

${ }^{2}$ Cows were fed a control, basal diet containing $44 \%$ forage and 56\% concentrate mix (CTL) or a basal diet supplemented with (DM basis) $2.7 \%$ Ca-PFO (FO), $2.7 \% \mathrm{Ca}-\mathrm{PFO}+5 \%$ full-fat extruded soybeans (FOESM) or $2.7 \% \mathrm{Ca}-\mathrm{PFO}+0.75 \%$ soybean oil (FOSO).

${ }^{3} \mathrm{SEM}=$ Standard error of least square means.

${ }^{4}$ Significance for treatment effect.

${ }^{5}$ CLA = Conjugated linoleic acid; sum of cis-9, trans-11 CLA (CLA-1) and trans-10, cis-12 CLA (CLA-2) isomers.

${ }^{6} \mathrm{Sum}$ of $\mathrm{C}_{18: 3} c-9,12,15 ; \mathrm{C}_{20: 3} c-11,14,17 ; \mathrm{C}_{20: 5}$ (DHA); $\mathrm{C}_{22: 5}$; and $\mathrm{C}_{22: 6}$ (EPA).

${ }^{7} \mathrm{Sum}$ of $\mathrm{C}_{18: 2}, \mathrm{C}_{18: 3} c-6,9,12 ; \mathrm{C}_{20: 3} c-8,11,14 ; \mathrm{C}_{20: 4} ;$ and $\mathrm{C}_{22: 4}$.

$* P<0.05 ; * * P<0.01 ; * * * P<0.001$.

(Dhiman et al., 1999b). The higher levels of CLA found in the FOESM and FOSO in milk and cheese compared with FO is due to available linoleic acid in the oil for ruminal synthesis of CLA. The proportion of CLA-1 was highest in milk FA when Ca-PFO was fed along with free soybean oil (FOSO) compared soybean oil through full-fat extruded soybeans (FOESM) or when $\mathrm{Ca}-\mathrm{PFO}$ was fed alone. This was probably because there was more VA available for the mammary gland to convert to CLA in this treatment. Total CLA (CLA-
1 and CLA-2) was higher in milk and cheese for the FO, FOESM, and FOSO treatments compared with the control. As mentioned earlier, previous studies have shown that addition of fish oil in free form alone or in combination with soybeans increases CLA, usually accompanied by the depression of DMI, milk yield, or milk fat and protein content (Chouinard et al., 1999; Baer et al., 2001; Whitlock et al., 2002). In the present study, addition of Ca-PFO alone or in combination with extruded full-fat soybeans or soybean oil increased the 
Table 5. Estimated $\Delta^{9}$-desaturase activity of milk fatty acids in the mammary gland of cows fed Ca salts of palm and fish oil (Ca-PFO) alone or in combination with soybean products

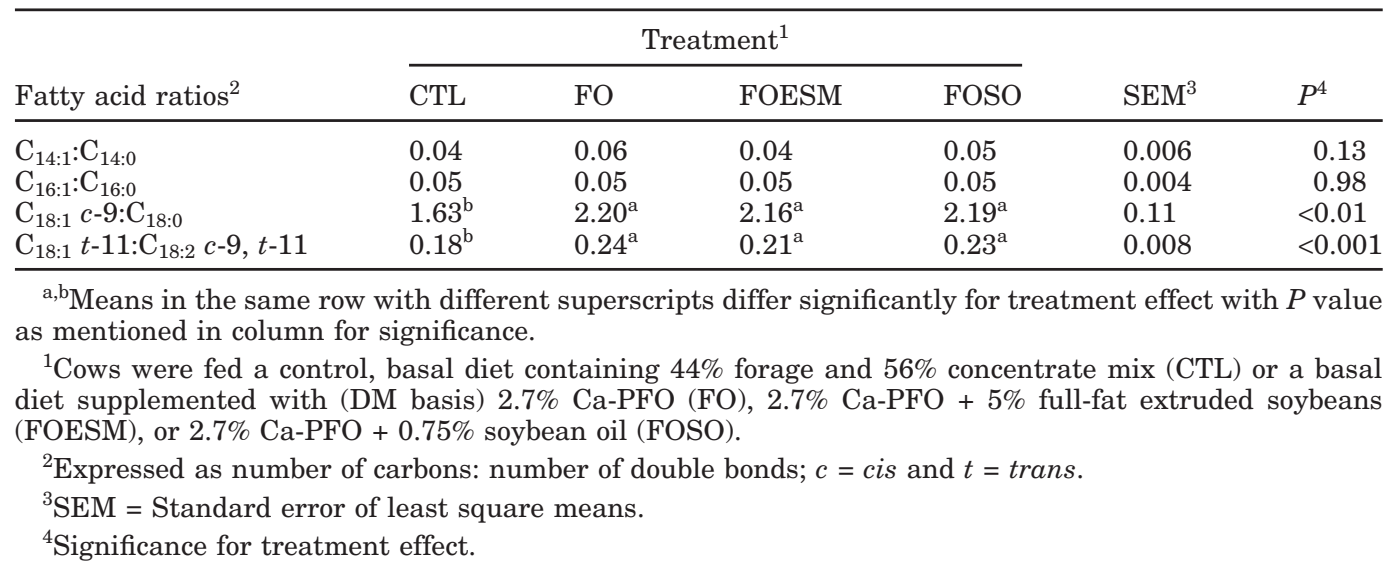

CLA content of milk and cheese while maintaining similar DMI, milk yields, and protein contents as the control, except there was a tendency for decreased fat content in the FOSO treatment. As discussed earlier, even a small decrease in milk fat could be of significant economic value to dairy producers. The Ca-PFO is in granular form and is easy to handle on the farm. Thus, from a practical point of view, adding Ca-PFO is more convenient and did not cause any negative effects in the present study. However, its use will depend on the economic returns, which needs further investigation.

The VA is a source for CLA synthesis in the mammary gland. Higher CLA levels are correlated with higher levels of VA in Table 4. It is important to estimate the index of the $\Delta^{9}$-desaturase enzyme, which is responsible for the conversion of VA to CLA. Corl et al. (2001) concluded, in research focusing on the enzyme $\Delta^{9}$-desaturase, that the major site for synthesis of this enzyme is the mammary gland in lactating cows. An increase in the CLA content of milk can be partially attributed to the increased index of the $\Delta^{9}$ desaturase. There was no treatment by week interaction for the $\Delta^{9}$-desaturase enzyme index, so average values for 4,5 , and $6 \mathrm{wk}$ are given in Table 5 . The $\Delta^{9}$ desaturase index for $\mathrm{C}_{14: 1}: \mathrm{C}_{14: 0}$ and $\mathrm{C}_{16: 1}: \mathrm{C}_{16: 0}$ was not different among treatments. However, there was a increase in $\Delta^{9}$-desaturase index in the FO, FOESM, and FOSO over the control for $\mathrm{C}_{18: 1}$ cis-9: $\mathrm{C}_{18: 0}$ and VA:CLA1. The increase in CLA-1 content of milk in FO, FOESM, and FOSO may be partially attributed to the increase in $\Delta^{9}$-desaturase enzymatic activity in the mammary gland of cows in these treatments. It is important to point out here that higher levels of CLA-1 in FOSO without further increase in $\Delta^{9}$-desaturase index compared with FO suggest that source of CLA1 in this treatment was through the rumen rather than through the mammary gland.
The proportions of EPA tended to increase, but the proportions of C22:5 and DHA were significantly higher in milk and cheese FA from FO, FOESM, and FOSO treatments than from the control treatment. Other researchers have shown an increase in EPA, DPA, and DHA in milk from cows supplemented with fish oil or extruded soybeans (Baer et al., 2001; Ramaswamy et al., 2001; Whitlock et al., 2002). Total n-3 FA were similar for the FO, FOESM, and FOSO in milk and cheese, but higher than the control treatment. In the present study, feeding Ca-PFO provided some n3 FA for direct absorption in the small intestine, allowing greater levels of n-3 FA to be taken into the mammary gland and then into the milk. Absorption efficiency of n-3 FA from diet to milk was not determined in the present study.

The ratio between n-3:n-6 FA tended to increase (Table 4) in the FO, FOESM, and FOSO treatments in milk and was higher in cheese (average $=0.13 ; P<$

Table 6. Influence of treatment diet fed to dairy cows on the atherogenic and thrombogenic indices of milk and Cheddar cheese

\begin{tabular}{llllll}
\hline & \multicolumn{4}{c}{ Treatment $^{1}$} \\
\cline { 2 - 4 } Item & CTL & FO & FOESM & FOSO & SEM $^{2}$ \\
\hline Milk & & & & & \\
$\quad$ Atherogenic & $2.51^{\mathrm{a}}$ & $1.82^{\mathrm{b}}$ & $1.59^{\mathrm{b}}$ & $1.69^{\mathrm{b}}$ & 0.07 \\
$\quad$ Thrombogenic & $1.86^{\mathrm{a}}$ & $1.60^{\mathrm{b}}$ & $1.47^{\mathrm{b}}$ & $1.52^{\mathrm{b}}$ & 0.05 \\
Cheddar cheese & & & & & \\
$\quad$ Atherogenic & $2.47^{\mathrm{a}}$ & $1.77^{\mathrm{b}}$ & $1.57^{\mathrm{c}}$ & $1.64^{\mathrm{c}}$ & 0.04 \\
Thrombogenic & $2.99^{\mathrm{a}}$ & $2.63^{\mathrm{b}}$ & $2.43^{\mathrm{c}}$ & $2.64^{\mathrm{b}}$ & 0.03 \\
\hline
\end{tabular}

${ }^{\mathrm{a}, \mathrm{b}, \mathrm{c}}$ Means in the same row with different superscripts differ $(P<$ 0.001) for treatment effects.

${ }^{1}$ Cows were fed a control, basal diet containing $44 \%$ forage and $56 \%$ concentrate mix (CTL) or a basal diet supplemented with (DM basis) $2.7 \%$ Ca salts of palm and fish oil (Ca-PFO; FO), $2.7 \% \mathrm{Ca}-\mathrm{PFO}$ $+5 \%$ full-fat extruded soybeans (FOESM), or $2.7 \% \mathrm{Ca}-\mathrm{PFO}+0.75 \%$ soybean oil (FOSO).

${ }^{2} \mathrm{SEM}=$ Standard error of least square means. 
Table 7. Influence of fatty acid (FA) methylation method on selected FA in Cheddar cheese

\begin{tabular}{|c|c|c|c|}
\hline \multirow[b]{2}{*}{$\mathrm{FA}^{2}$} & \multicolumn{2}{|c|}{ Method of methylation $^{1}$} & \multirow[b]{2}{*}{$\mathrm{SEM}^{3}$} \\
\hline & Acid & Alkaline & \\
\hline & \multicolumn{3}{|c|}{$-(\mathrm{g} / 100 \mathrm{~g}$ of total FA) -} \\
\hline $\mathrm{C}_{18: 1} t-11$ & 5.25 & 4.75 & 0.04 \\
\hline $\mathrm{C}_{18: 2} c-9, t-11$ & 1.16 & 1.30 & 0.01 \\
\hline $\mathrm{C}_{18: 2} t-10, c-12$ & 0.06 & 0.09 & 0.001 \\
\hline Total CLA ${ }^{4}$ & 1.22 & 1.38 & 0.01 \\
\hline Total n-3 FA ${ }^{5}$ & 0.69 & 0.87 & 0.004 \\
\hline Total $n-6 \mathrm{FA}^{6}$ & 5.41 & 5.48 & 0.02 \\
\hline n-3:n-6 FA & 0.13 & 0.16 & 0.001 \\
\hline
\end{tabular}

${ }^{1}$ Means in the same row $\operatorname{differ}(P<0.001)$ for method of methylation effect.

${ }^{2}$ Only FA of interest have been reported; $c=c i s ; t=$ trans.

${ }^{3} \mathrm{SEM}=$ Standard error of least square means.

${ }^{4} \mathrm{Sum}$ of $\mathrm{C}_{18: 2} c-9, t-11$ CLA and $\mathrm{C}_{18: 2} t-10, c-12$ CLA isomers.

${ }^{5} \mathrm{Sum}$ of $\mathrm{C}_{18: 3} c-9,12,15 ; \mathrm{C}_{20: 3} c-11,14,17 ; \mathrm{C}_{20: 5}$ (docosahexaenoic acid); $\mathrm{C}_{22: 5}$; and $\mathrm{C}_{22: 6}$ (eicosapentaenoic acid).

${ }^{6} \mathrm{Sum}$ of $\mathrm{C}_{18: 2} ; \mathrm{C}_{18: 3} \mathrm{c}-6,9,12 ; \mathrm{C}_{20: 3} c-8,11,14 ; \mathrm{C}_{20: 4} ;$ and $\mathrm{C}_{22: 4}$.

0.01) compared with the control (0.12). It is not known with certainty what the optimum or desirable dietary ratio of n-3:n6 FA is for humans. However, current evidence suggests that the ratio between n-3:n-6 FA of 0.20 or lower is probably reasonable, whereas a value of 0.02 is undoubtedly excessive (Givens et al., 2000). Feeding Ca-PFO alone or in combination with extruded full-fat soybeans or soybean oil decreased the proportion of saturated FA and increased the unsaturated FA in milk and cheese compared with the control. This decrease in saturated FA and increase in unsaturated FA was greater in FOESM and FOSO compared with the FO treatment, reflecting the dietary supply. The average unsaturated:saturated FA ratio in the present study was $0.50,0.66,0.73$, and 0.71 in the

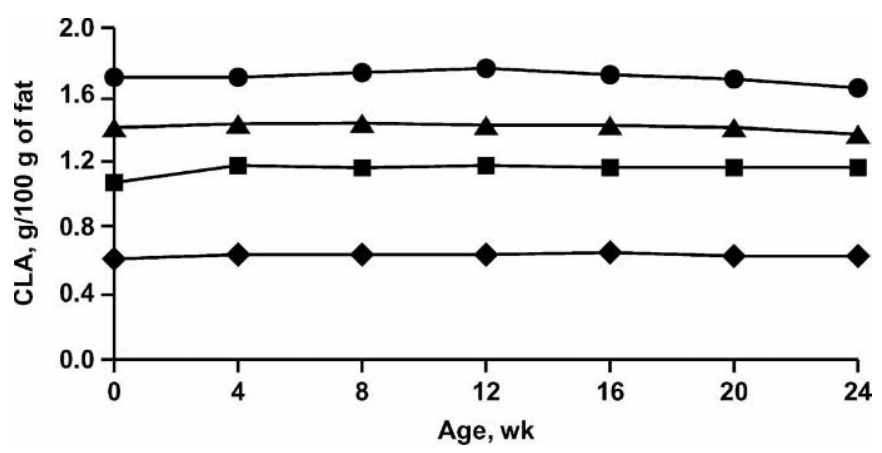

Figure 1. Effect of age on the total conjugated linoleic acid (CLA; sum of $\mathrm{C}_{18 \cdot 2}$ cis-9,trans-11 and $\mathrm{C}_{18.2}$ trans-10,cis-12 isomers) content of Cheddar cheese from cows fed a control, basal diet ( $\bullet$ ); the basal diet $+2.7 \%$ Ca salts of palm and fish oil (Ca-PFO; $\mathbf{\square})$; the basal diet $+2.7 \% \mathrm{Ca}-\mathrm{PFO}+5 \%$ full-fat extruded soybeans $(\boldsymbol{\Delta})$; or the basal diet $+2.7 \% \mathrm{Ca}-\mathrm{PFO}+0.75 \%$ of dietary DM as soybean oil $(\mathbf{)}$. control, FO, FOESM, and FOSO treatments, respectively (Table 4). The relationship between saturated FA intake and low density lipoprotein in humans is direct and progressive, increasing the risk of cardiovascular disease (Clarke et al., 1997). The increase in the proportions of CLA, VA, n-3, and unsaturated FA in milk by feeding Ca-PFO alone or in combination with soybean products resulted in milk and cheese with higher nutritive and therapeutic value.

Dietary fats and oils have been associated with increased incidence of cardiovascular disease, namely coronary heart disease that is caused primarily by atherosclerosis or coronary thrombosis. The link between dairy fat consumption and risk of coronary heart disease is weak (Ness et al., 2001). None the less, dairy products with lower AI and TI indicate that they are less likely to cause atherosclerosis or coronary thrombosis, thus being potentially healthier for humans. The $\mathrm{AI}$ and TI of milk and cheese FA in the FO, FOESM, and FOSO were lower than in the control (Table 6), indicating that milk and cheese from treatment cows fed Ca-PFO alone or in combination with soybean products are less likely to lead to atherosclerosis and coronary thrombosis than milk from cows fed the control treatment.

Calculations were made to compare the value of milk from different treatments to supply CLA and EPA + DHA FA to humans. Based on appropriate extrapolation of data from small animals to humans, an adult human would require 0.72 to $0.80 \mathrm{~g}$ of CLA/d to inhibit tumor growth (Parrish et al., 2003). Correcting milk fat for glycerol content (Chouinard et al., 2001), based on fat and CLA contents of milk in this study, $500 \mathrm{~mL}$ of milk from control, FO, FOESM, and FOSO treatments would provide $0.093,0.186,0.211$, and $0.231 \mathrm{~g}$ of CLA. Using CLA contents of cheese in the current study and a fat content of $32 \%, 100 \mathrm{~g}$ of cheese from control, FO, FOESM, and FOSO treatments would provide 0.178 , $0.321,0.397$, and $0.479 \mathrm{~g}$ of CLA. A person consuming $500 \mathrm{~mL}$ of milk and $100 \mathrm{~g}$ of cheese daily from cows on the control treatment would only be consuming about $35 \%$ of the estimated requirement for humans. However, consuming similar amounts of milk and cheese from cows on FO, FOESM, and FOSO treatments would provide 67,80 , and $93 \%$ of the estimated daily requirements of CLA, respectively. In addition, there is a potential for higher levels of VA in CLAenriched dairy products to be converted to CLA in human tissues. Turpeinen et al. (2002) reported that $20 \%$ of the VA was converted to CLA in human tissues, further increasing the supply of CLA that could be obtained from enriched products. Clearly, if the objective is to achieve health benefits from CLA, it is practical to consume CLA-enriched milk and cheese. 
Table 8. Sensory scores for trained panel evaluation of milk and Cheddar cheese from cows fed Ca salts of palm and fish oil (Ca-PFO) alone or in combination with soybean products

\begin{tabular}{|c|c|c|c|c|c|c|c|}
\hline \multirow[b]{2}{*}{ Item } & \multicolumn{5}{|c|}{ Treatment ${ }^{1}$} & \multirow[b]{2}{*}{$\mathrm{SEM}^{2}$} & \multirow[b]{2}{*}{$P^{3}$} \\
\hline & CTL & FO & FOESM & FOSO & STORE & & \\
\hline \multicolumn{8}{|l|}{ Milk } \\
\hline \multicolumn{8}{|l|}{ Flavor } \\
\hline Acid & 1.36 & 1.39 & 1.39 & 1.29 & 1.57 & 0.12 & 0.57 \\
\hline Barny & $1.04^{\mathrm{b}}$ & $1.12^{\mathrm{b}}$ & $1.18^{\mathrm{ab}}$ & $1.04^{\mathrm{b}}$ & $1.46^{\mathrm{a}}$ & 0.08 & $<0.01$ \\
\hline Cooked & 2.29 & 2.14 & 2.43 & 2.29 & 2.50 & 0.21 & 0.77 \\
\hline Feed & $1.32^{\mathrm{b}}$ & $1.39^{\mathrm{b}}$ & $1.64^{\mathrm{b}}$ & $1.50^{\mathrm{b}}$ & $2.32^{\mathrm{a}}$ & 0.16 & $<0.01$ \\
\hline Fermented & 1.21 & 1.25 & 1.21 & 1.00 & 1.21 & 0.14 & 0.74 \\
\hline Foreign & 1.21 & 1.29 & 1.36 & 1.36 & 1.29 & 0.17 & 0.97 \\
\hline Stale & 2.11 & 2.04 & 1.93 & 2.64 & 2.46 & 0.24 & 0.18 \\
\hline Oily & 1.21 & 1.00 & 1.07 & 1.25 & 1.11 & 0.11 & 0.44 \\
\hline Oxidized & 1.68 & 1.75 & 1.71 & 2.50 & 2.21 & 0.31 & 0.24 \\
\hline Rancid & 1.07 & 1.07 & 1.00 & 1.00 & 1.04 & 0.04 & 0.59 \\
\hline Other & 1.07 & 1.00 & 1.00 & 1.21 & 1.21 & 0.09 & 0.26 \\
\hline Overall quality & 7.29 & 7.11 & 7.11 & 6.54 & 5.89 & 0.40 & 0.10 \\
\hline \multicolumn{8}{|l|}{ Cheese } \\
\hline \multicolumn{8}{|l|}{ Flavor } \\
\hline Acid & $4.30^{\mathrm{ab}}$ & $3.87^{\mathrm{b}}$ & $4.43^{\mathrm{a}}$ & $4.39^{\mathrm{ab}}$ & & 0.15 & 0.03 \\
\hline Bitter & 3.37 & 3.30 & 3.63 & 3.54 & & 0.19 & 0.57 \\
\hline Color & 3.57 & 3.52 & 3.54 & 3.54 & & 0.10 & 0.99 \\
\hline Feed & 1.35 & 1.37 & 1.39 & 1.44 & & 0.08 & 0.84 \\
\hline Fermented & 1.74 & 1.57 & 1.53 & 1.67 & & 0.11 & 0.53 \\
\hline Flat & 1.76 & 2.20 & 2.00 & 1.96 & & 0.12 & 0.07 \\
\hline Oily & 1.41 & 1.56 & 1.54 & 1.56 & & 0.09 & 0.56 \\
\hline Oxidized & 2.07 & 2.22 & 2.13 & 2.22 & & 0.16 & 0.88 \\
\hline Rancid & 1.52 & 1.63 & 1.65 & 1.57 & & 0.09 & 0.71 \\
\hline Sulfide & 1.74 & 1.65 & 1.76 & 1.83 & & 0.11 & 0.70 \\
\hline Unclean & 1.63 & 1.96 & 1.80 & 1.80 & & 0.15 & 0.49 \\
\hline Other & 1.33 & 1.57 & 1.74 & 1.56 & & 0.14 & 0.21 \\
\hline Overall quality & 5.45 & 5.08 & 4.80 & 4.99 & & 0.18 & 0.09 \\
\hline
\end{tabular}

${ }^{\mathrm{a}, \mathrm{b}}$ Means in the same row with different superscripts differ significantly for treatment effect with $P$ value as mentioned in column for significance.

${ }^{1}$ Cows were fed a control, basal diet containing $44 \%$ forage and $56 \%$ concentrate mix (CTL) or a basal diet supplemented with (DM basis) 2.7\% Ca-PFO (FO), 2.7\% Ca-PFO + 5\% full-fat extruded soybeans (FOESM), or $2.7 \% \mathrm{Ca}-\mathrm{PFO}+0.75 \%$ soybean oil $(\mathrm{FOSO})$. $\mathrm{STORE}=$ store-bought whole milk with at least 14-d shelf-life.

${ }^{2} \mathrm{SEM}=$ Standard error of least square means.

${ }^{3}$ Significance for treatment effect.

The recommended daily intakes of EPA + DHA for humans were presented in the workshop on the essentiality of these FA and were agreed upon by the workshop participants (Simopoulos et al., 1999). According to the workshop, the recommended daily intake for $\mathrm{EPA}+\mathrm{DHA}$ is $650 \mathrm{mg} / \mathrm{d}$, and one $500-\mathrm{mL}$ serving of milk from cows on the control treatment would meet $1.2 \%$ of this requirement. Milk from cows fed the FO, FOESM, and FOSO treatments would meet 2.9, 2.3, and $2.0 \%$ of the recommended daily intake. By manipulating cow's diet in the present study, we were not able to enrich milk with EPA and DHA to a level that would provide a significant portion of recommended daily intake, probably because of inherently low EPA and DHA content of milk and low transfer efficiency from diet to milk fat.

Although the acid methylation procedure was used for the esterification of milk FA, it is recognized as being less efficient for CLA analysis than the alkaline methylation. This decreased precision is due to the isomerization of CLA and the possible production of methoxy artifacts that can occur in the acid methylation procedure (Park et al., 1999). Cheese samples for each treatment were also analyzed using an alkaline methylation procedure and compared with the proportion of CLA and n-3 FA recovered using acid methylation. There was no treatment by method interaction, so results for VA, CLA, and n-FA are presented as an average across treatments (Table 7). When comparing the two methylation procedures, there was an increase in the recovery of CLA-1, CLA-2, total n-3 FA, and n$3: n-6$ ratio by $10.7,33.3,20.7$, and $18.8 \%$ with the use of an alkaline methylation procedure, respectively. A similar increase in the proportion of CLA and n-3 FA compared with acid methylation could also be expected 
Table 9. Influence of age on flavor scores for Cheddar cheese from cows fed a basal diet supplemented with $2.7 \%$ Ca salts of palm and fish oil (Ca-PFO) plus $0.75 \%$ of dietary DM as soybean oil (FOSO)

\begin{tabular}{lllllr}
\hline & \multicolumn{4}{c}{ Age $^{1}$} & \\
\cline { 2 - 3 } & Mild & Medium & Sharp & SEM $^{2}$ & \\
\hline Flavor & & & & \\
Feed & $1.17^{\mathrm{b}}$ & $1.83^{\mathrm{a}}$ & $1.33^{\mathrm{ab}}$ & 0.18 & 0.02 \\
Oily & $1.22^{\mathrm{b}}$ & $1.94^{\mathrm{a}}$ & $1.50^{\mathrm{ab}}$ & 0.21 & 0.04 \\
Oxidized & $1.67^{\mathrm{b}}$ & $3.17^{\mathrm{a}}$ & $1.83^{\mathrm{b}}$ & 0.38 & $<0.01$ \\
Rancid & $1.28^{\mathrm{b}}$ & $2.11^{\mathrm{a}}$ & $1.33^{\mathrm{b}}$ & 0.15 & $<0.01$ \\
Sulfide & $1.11^{\mathrm{b}}$ & $2.28^{\mathrm{a}}$ & $2.11^{\mathrm{a}}$ & 0.27 & \\
\hline
\end{tabular}

${ }^{\mathrm{a}, \mathrm{b}}$ Means in the same row with different superscripts differ significantly for treatment effect with $P$ value as mentioned in column for significance.

${ }^{1}$ Mild Cheddar cheese $=21$ to $30 \mathrm{~d}$ of aging in a vacuum-packaged air-tight bag at $4^{\circ} \mathrm{C}$, medium Cheddar cheese $=$ approximately $90 \mathrm{~d}$ of aging, and sharp Cheddar cheese $=180+\mathrm{d}$ of aging.

${ }^{2} \mathrm{SEM}=$ Standard error of least square means.

in milk FA when using an alkaline methylation procedure (Table 4).

\section{Sensory Evaluation of Milk and Cheese}

Scores from the trained sensory panel for milk and cheese showed no treatment by week interaction; therefore, the values for the 2 -wk tests were averaged (Table 8). Lower scores by the taste panelists indicate a less pronounced physical or flavor characteristic. Trained taste panelists did not observe any off flavor in milk from all treatments including the control. The overall quality of milk was the same across treatments. However, store milk had barny and feed flavor characteristics compared with the treatment milk. There was a tendency toward overall lower quality of the store milk compared with the treatment milk. This may partially be because milk purchased at the store was in a non-light shielding plastic container. We recommend that store milk in a colored plastic jug or paperboard container should be used in future experiments to assure the quality of milk.

Baer et al. (2001) and Ramaswamy et al. (2001) reported no difference in oxidized flavor in milk supplemented with fish oil at $2 \%$ of the dietary DM. Physical characteristics and flavors detected by the taste panelists that were not specified on the scorecard were placed in the "other" category. The flavors flat, metallic, and bitter were detected by a few panelists and were placed in the "other" category.

The taste panelists found no flavor difference among treatments in cheese except for the acid flavor (below slightly perceptible level), which was lower in the FO treatment than in the FOESM treatment, but not different than the control or FOSO treatments (Table 8). Although statistically there was no difference in overall quality scores for the treatments, there was a tendency for decrease in the FO, FOESM, and FOSO treatments compared with the control. Some of the characteristics detected by the panelists, but not included on the scorecard were soft, bland, salty, citric, and metallic, which were placed in the "other" category. Results from the present study suggest that sensory scores and consumer acceptability characteristics of milk and cheese were comparable for FO, FOESM, and FOSO with those from the control treatment.

As cheese ages, residual coagulant and enzymes from starter culture and nonstarter lactic acid bacteria hydrolyze the milk proteins converting them into peptides, amino acids, and other flavor compounds. Some breakdown of triglycerides also occurs, releasing free FA, although lipolytic activity is generally less than proteolytic activity in a cheese such as Cheddar cheese. The longer the cheese is stored, the more distinctive the cheese flavor becomes. Along with the generation of flavor compounds that impart the characteristic flavor of Cheddar cheese, there can also be other compounds produced that impart off-flavors such as bitter, oxidized, and rancid flavors.

There was a significant treatment by age interaction observed for flavor characteristics of the cheeses as they were aged from mild ( 21 to $30 \mathrm{~d}$ of storage) to sharp (180 d of storage). There were no pronounced changes in off-flavors detected by the sensory panel for the control treatment cheese during the $180 \mathrm{~d}$ of aging, and only slight (but nonsignificant) increase in the flat and oxidized flavors were observed in the FO and FOESM treatment cheeses (data not shown). The FOSO treatment cheese exhibited the most change in off-flavor. For the FOSO treatment cheese, there were significant changes in feed, oily, oxidized, rancid, and sulfide flavor characteristics, although these were still only at the level of 3 (barely perceptible) or less (Table 9 ). The largest change was for oxidized flavor, which was most pronounced in the medium cheese and then diminished back to its original level when further aged 
to sharp. Changes in the other flavor characteristics followed a similar pattern but did not reach the same level of pronouncement as oxidized flavor. This increase in oxidized flavor may reflect the increased level of unsaturated FA in the milk from cows fed supplemental fat, especially those supplemented with soybean oil in addition to Ca-PFO. The decrease in sensory scores for these flavor characteristics as the cheese was aged from 90 to $180 \mathrm{~d}$ probably came about because as the overall cheese flavor increases to become a "sharp" rather than "medium" cheese, the off-flavors would be less apparent.

Cheese samples from all treatments were also tested for FA profiles every $4 \mathrm{wk}$ for $24 \mathrm{wk}$ to determine the influence of aging of cheese on FA content. There was no influence of cheese age on any of the FA including CLA or n-FA. Data for the effect of aging on total CLA content of Cheddar cheese is shown in Figure 1. Results from the present study suggest that there were no major changes in the flavor characteristics and CLA or n-3 FA of CLA enriched cheese when it was aged to sharp Cheddar.

\section{CONCLUSIONS}

The addition of Ca-PFO alone or in combination with full-fat extruded soybeans and soybean oil increased the CLA, VA, n-3, and unsaturated FA content in milk and cheese with potential human health benefits without altering feed intake, milk yield, and milk composition of dairy cows in the present study. Fatty acid composition of cheese followed the same trends as in milk, suggesting that processing CLA enriched milk into Cheddar cheese did not alter the FA composition.

Partially ruminally inert Ca salts of palm and fish oil can be used at a level of $2.7 \%$ of dietary DM in combination with extruded full-fat soybeans or soybean oil for feeding to dairy cows to enhance the CLA, VA, unsaturated, and n-3 FA in milk fat without negatively impacting the animal performance and overall quality and consumer acceptability of milk and cheese.

\section{ACKNOWLEDGMENTS}

The authors thank Jeffrey L. Walters, Department of Animal, Dairy and Veterinary Sciences, Utah State University, for technical help during the preparation of this manuscript. The authors also acknowledge Stephan L. Larsen and Randall Bagley, Western Dairy Research Center, for their help with milk processing and cheese manufacturing.

\section{REFERENCES}

AOAC. 2000. Official Methods of Analysis. Vol. I. 17th ed. Assoc. Off. Anal. Chem., Washington, DC.
Baer, R. J., J. Ryali, D. J. Schingoethe, K. M. Kasperson, D. C. Donovan, A. R. Hippen, and S. T. Franklin. 2001. Composition and properties of milk and butter from cows fed fish oil. J. Dairy Sci. 84:345-353.

Calder, P. C., 2001. Polyunsaturated fatty acids, inflammation, and immunity. Lipids 36:1007-1024.

Chin, S. F., W. Liu, J. M. Storkson, Y. L. Ha, and M. W. Pariza. 1992. Dietary sources of conjugated dienoic isomers of linoleic acid, a newly recognized class of anti-carcinogens. J. Food Comp. Anal. 5:185-197.

Chouinard, P. Y., L. Corneau, D. M. Barbano, L. E. Metzger, and D. E. Bauman. 1999. Conjugated linoleic acid alters milk fatty acid composition and inhibits milk fat secretion in dairy cows. J. Nutr. 129:1579-1584.

Chouinard, P. Y., L. Corneau, W. R. Butler, Y. Chilliard, J. K. Drackley, and D. E. Bauman. 2001. Effect of dietary lipid source on conjugated linoleic acid concentrations in milk fat. J. Dairy Sci. 84:680-690.

Clarke, R., C. Frost, R. Collins, P. Appleby, and R. Peto. 1997. Dietary lipids and blood cholesterol: Quantitative meta-analysis of metabolic ward studies. Br. Med. J. 314:112-117.

Corl, B. A., L. H. Baumgard, D. A. Dwyer, J. M. Griinari, B. S. Phillips, and D. E. Bauman. 2001. The role of delta(9)-desaturase in the production of cis-9, trans-11 CLA. J. Nutr. Biochem. 12:622-630.

Demeyer, D. and M. Doreau. 1999. Targets and procedures for altering ruminant meat and milk lipids. Proc. Nutr. Soc. 58:593-607.

Dhiman, T. R., G. R. Anand, L. D. Satter, and M. W. Pariza. 1999a. Conjugated linoleic acid content of milk from cows fed different diets. J. Dairy Sci. 82:2146-2156.

Dhiman, T. R., E. D. Helmink, D. J. McMahon, R. L. Fife, and M. W. Pariza. 1999b. Conjugated linoleic acid content of milk and cheese from cows fed extruded oilseeds. J. Dairy Sci. 82:412-419.

Dhiman, T. R., M. S. Zaman, I. S. MacQueen, and R. L. Boman. 2002. Influence of corn processing and frequency of feeding on cow performance. J. Dairy Sci. 85:217-226.

Donovan, D. C., D. J. Schingoethe, R. J. Baer, J. Ryali, A. R. Hippen, and S. T. Franklin. 2000. Influence of dietary fish oil on conjugated linoleic acid and other fatty acids in milk fat from lactating dairy cows. J. Dairy Sci. 83:2620-2628.

Givens, D. I., B. R. Cottrill, M. Davies, P. A. Lee, R. J. Mansbridge, and A. R. Moss. 2000. Sources of n-3 polyunsaturated fatty acids additional to fish oil for livestock diets-a review. Nutr. Abstr. Rev. 70:1-19.

Hammond, E., W. Dunkley, F. Bodyfelt, E. Larmond, and R. Lindsay. 1986. Report of the committee on sensory data to the journal management committee of the American Dairy Science Association. J. Dairy Sci. 69:298.

Hughes, C. L. and T. R. Dhiman. 2002. Dietary compounds in relation to dietary diversity and human health. J. Med. Food. 5:51-68.

Hurley, W. L., G. J. Warner, and R. R. Grummer. 1987. Changes in triglyceride fatty acid composition of mammary secretions during involution. J. Dairy Sci. 70:2406-2410.

Jenkins, T. C. 1993. Lipid metabolism in the rumen. J. Dairy Sci. 76:3851-3863.

Kay, J. K., T. R. Mackle, M. J. Auldist, N. A. Thomsom, and D. E. Bauman. 2004. Endogenous synthesis of cis-9, trans-11 conjugated linoleic acid in dairy cows fed fresh pasture. J. Dairy Sci. 87:369-378.

Kramer, J. K. G., V. Fellner, M. E. R. Dugan, F. D. Sauer, M. M. Mossoba, and M. P. Yurawecz. 1997. Evaluating acid and base catalysts in the methylation of milk and rumen fatty acids with special emphasis on conjugated dienes and total trans fatty acids. Lipids 32:1219-1228.

Kromhout, D. 1989. Fish (oil) consumption and coronary heart disease. Page 273-282 in Dietary Omega-3 and Omega-6 Fatty Acids. Biological Effects and Nutritional Essentiality. C. Galli and A. P. Simopoulos, ed. Plenum Publishing. New York, NY.

Lundy, F. P., E. Block, W. C. Bridges, Jr., J. A. Bertrand, and T. C. Jenkins. 2004. Ruminal biohydrogenation in Holstein cows 
fed soybean fatty acids as amides or calcium salts. J. Dairy Sci. 87:1038-1046.

Murrieta, C. M., B. W. Hess, and D. C. Rule. 2003. Comparison of acidic and alkaline catalysts for preparation of fatty acid methyl esters from ovine muscle with emphasis on conjugated linoleic acid. Meat Sci. 65:523-529.

National Research Council. 2001. Nutrient Requirements of Dairy Cattle. 7th ed. Natl. Acad. Sci., Washington, DC.

Ness, A. R., G. Davey Smith, and C. Hart. 2001. Milk, coronary heart disease and mortality. J. Epidemiol. Community Health 55:379-382.

Pariza, M. W. 1999. The biological activities of conjugated linoleic acid. Pages 12-20 in Advances in Conjugated Linoleic Acid Research. Vol. I. M. P. Yurawecz, M. M. Mossoba, J. K. G. Kramer, M. W. Pariza, and G. J. Nelson, ed. AOCS Press, Champaign, IL.

Park, Y., J. M. Storkson, K. J. Albright, W. Liu, and M. W. Pariza. 1999. Evidence that trans-10, cis-12 isomer of conjugated linoleic acid induces body fat composition changes in mice. Lipids 34:235-241.

Parodi, P. W. 1994. Conjugated linoleic acid: An anticarcinogenic fatty acid present in milk fat. Aust. J. Dairy Technol. 40:93-97.

Parrish, F. C., Jr., B. R. Wiegand, D. C. Beitz, D. U. Ahn, M. Du, and A. H. Trenkle. 2003. Use of dietary CLA to improve composition and quality of animal-derived foods. Pages 189-217 in Advances in Conjugated Linoleic Acid Research. Vol. II. J. L. Sebebio, W. W. Christie, and R. Adlof, ed. AOCS Press, Champaign, IL

Ramaswamy, N., R. J. Baer, D. J. Schingoethe, A. R. Hippen, K. M. Kasperson, and L. A. Whitlock. 2001. Composition and flavor of milk and butter from cows fed fish oil, extruded soybeans, or their combination. J. Dairy Sci. 84:2144-2151.
SAS. 1999-2000. SAS/STAT User's Guide (Release 8.1), SAS Inst., Inc., Cary, NC.

Simopoulos, A. P. 1999. Proceedings from the workshop on the essentiality of and dietary reference intakes (DRI's) for omega- 6 and omega-3 fatty acids. The Cloisters, National Institutes of Health, Bethesda, MD.

Sukhija, P. S., and D. L. Palmquist. 1988. Rapid method for determination of total fatty acid content and composition of feedstuffs and feces. J. Agric. Food Chem. 36:1202-1206.

Turpeinen, A. M., M. Mutanen, A. Aro, I. Salminen, S. Basu, D. L. Palmquist, and J. M. Griinari. 2002. Bioconversion of vaccenic acid to conjugated linoleic acid in humans. Am. J. Clin. Nutr. 76:504-510.

Tyrrell, H. F., and J. T. Reid. 1965. Prediction of the energy value of cow's milk. J. Dairy Sci. 48:1215-1223.

Uauy, R., D. R. Hoffman, P. Peirano, D. G. Birch, and E. E. Birch. 2001. Essential fatty acids in visual and brain development. Lipids 36:885-895.

Ulbright, T. L. V., and D. A. T. Southgate. 1991. Coronary heart disease: Seven dietary factors. Lancet 338:985-992.

Van Soest, P. J., J. B. Robertson, and B. A. Lewis. 1991. Methods for dietary fiber, neutral detergent fiber, and non-starch polysaccharides in relation to animal nutrition. J. Dairy Sci. 74:3583-3597.

Vessby, B. 2000. Dietary fat and insulin activity in humans. Br. J. Nutr. 83:S91-S96.

Whitlock, L. A., D. J. Schingoethe, A. R. Hippen, K. F. Kalscheur, R. J. Baer, N. Ramaswamy, and K. M. Kasperson. 2002. Fish oil and extruded soybeans fed in combination increase conjugated linoleic acid in milk of dairy cows more than when fed separately. J. Dairy Sci. 85:234-243. 